\title{
Synthesis, Screening for Antiacetylcholinesterase Activity and Binding Mode Prediction of a New Series of [3-(Disubstituted-phosphate)-4,4,4-trifluoro-butyl]-Carbamic Acid Ethyl Esters
}

\author{
Nilo Zanatta, ${ }^{* a}$ Deise M. Borchhardt, ${ }^{a, b}$ Adriana D. Carpes, ${ }^{a, c}$ Tiago M. Marchi, ${ }^{a}$ \\ Adriano D. Andricopulo, ${ }^{b}$ Livia B. Salum, ${ }^{b}$ Maria R. C. Schetinger, ${ }^{c}$ Helio G. Bonacorso, ${ }^{a}$ \\ Marcos A. P. Martins ${ }^{a}$ and Alex F. C. Flores ${ }^{a}$ \\ ${ }^{a}$ Núcleo de Química de Heterociclos, Departamento de Química, Universidade Federal de Santa Maria, \\ 97105-900 Santa Maria-RS, Brazil
}

${ }^{b}$ Laboratório de Química Medicinal e Computacional, Centro de Biotecnologia Molecular Estrutural, Instituto de Física de São Carlos, Universidade de São Paulo, Av. Trabalhador São-Carlense 400, 13560-970 São Carlos-SP, Brazil

${ }^{c}$ Laboratório de Enzimologia Toxicológica, Departamento de Química, Universidade Federal de Santa Maria, 97105-900 Santa Maria-RS, Brazil

\begin{abstract}
Uma nova série de nove 3-fosfato-(4,4,4-trifluor-butil)-carbamatos de etila (compostos fosfatocarbamato), foram obtidos através da reação de (4,4,4-trifluor-3-hidroxibut-1-il)-etil carbamatos com oxicloreto de fósforo seguido de adição de álcoois. Os produtos foram caracterizados por espectroscopia de RMN de ${ }^{1} \mathrm{H},{ }^{13} \mathrm{C},{ }^{31} \mathrm{P}$ e ${ }^{19} \mathrm{~F}$, CG-EM e análise elementar. Todos os compostos sintetizados foram testados para a inibição da enzima acetilcolinesterase (AChE) usando o método de Ellman. Todos os compostos analisados contendo os grupos carbamato e fosfato em sua estrutura, mostraram inibição enzimática, sendo que o composto contendo o grupo dietóxi (2b) apresentou a maior atividade inibitória. Estudos de modelagem molecular foram realizados para obter informações detalhadas entre o sítio ativo da enzima acetilcolinesterase e os compostos candidatos a inibição, obtendo-se valiosas informações estruturais com relação à inibição de enzima acetilcolinesterase.
\end{abstract}

A series of nine new [3-(disubstituted-phosphate)-4,4,4-trifluoro-butyl]-carbamic acid ethyl esters (phosphate-carbamate compounds) was obtained through the reaction of (4,4,4-trifluoro-3hydroxybut-1-yl)-carbamic acid ethyl esters with phosphorus oxychloride followed by the addition of alcohols. The products were characterized by ${ }^{1} \mathrm{H},{ }^{13} \mathrm{C},{ }^{31} \mathrm{P}$, and ${ }^{19} \mathrm{~F}$ NMR spectroscopy, GC-MS, and elemental analysis. All the synthesized compounds were screened for acetylcholinesterase (AChE) inhibitory activity using the Ellman method. All compounds containing phosphate and carbamate pharmacophores in their structures showed enzyme inhibition, being the compound bearing the diethoxy phosphate group (2b) the most active compound. Molecular modeling studies were performed to investigate the detailed interactions between AChE active site and small-molecule inhibitor candidates, providing valuable structural insights into AChE inhibition.

Keywords: phosphate, carbamate, acetylcholinesterase, drug design

\section{Introduction}

The synthesis of new phosphorus-containing compounds has been attracting a great deal of attention due to their impressive chemical and biological profiles. ${ }^{1}$ Organophosphorus (OPs) compounds are important naturally occurring substrates in several biochemical

\footnotetext{
*e-mail: zanatta@base.ufsm.br
}

processes, and tetracoordinate pentavalent phosphorus compounds are well known biologically active compounds. ${ }^{2}$ The primary target for OPs is the acetylcholinesterase (AChE, EC 3.1.1.7), which is responsible for the regulation of cholinergic impulse. ${ }^{3}$ Furthermore, AChE is believed to play 'non-classical' roles in addition to its 'classical' role in terminating synaptic transmission (e.g. as an adhesion protein). Both of these actions involve the so-called 'peripheral' anionic site at the entrance to the 
active-site gorge. ${ }^{4}$ The $\mathrm{AChE}$ enzyme is an attractive target for therapeutic intervention not only because of its high catalytic efficiency, but also because of its important role in the central nervous system (CNS). ${ }^{5}$

The discovery of AChE inhibition, through the action of OPs compounds, allowed the development of insecticides and, to a limited extent, of new drugs. ${ }^{6}$ Both organophosphate and carbamate compounds have been extensively used as medicines and insecticides due to their inhibitory action of the AChE. ${ }^{7-10}$ Examples are Metrifonate, ${ }^{\circledR}$ used as antihelminthic and in the treatment of schistosamiasis, Echothiophate, ${ }^{\oplus}$ used for the treatment of glaucoma, ${ }^{11,12}$ and Rivastigmine ${ }^{\circledR}$ (a carbamate) used for the treatment of Alzheimer's disease. ${ }^{13}$

Therefore, phosphate and carbamate frameworks are important pharmacophores required for potent anticholinesterase activity. ${ }^{14-16}$ Although, carbamates and OPs are potent inhibitors of AChE, the two chemical groups differ in the stability of their complexes with AChE. ${ }^{17}$

In spite of the important molecular recognition process involved in AChE inhibition for either phosphate or carbamate groups, the presence of both chemical moieties in the same molecule (inhibitor) is rarely found in the literature. ${ }^{18,19}$ In the present work, we have synthesized and fully characterized by means of ${ }^{1} \mathrm{H},{ }^{13} \mathrm{C},{ }^{31} \mathrm{P}$ and ${ }^{19} \mathrm{~F}$ NMR spectroscopy, GC-MS, and elemental analysis, a new series of phosphate-carbamate compounds containing these two privileged pharmacophores in their structures, through the incorporation of phosphate groups in trifluoromethylated alcohols bearing a $\gamma$-ethyl carbamate function. In addition, the synthesized compounds were screened for AChE inhibitory activity and molecular modeling studies were subsequently carried out to investigate the preferred binding mode of these compounds in the AChE active site. It is worth noting that we described herein an efficient method for the synthesis of a new series of phosphate-carbamate compounds, using $\mathrm{POCl}_{3}$ as the phosphorilating reagent, instead of other traditional methods, with the advantage of reducing one reaction step.

\section{Results and Discussion}

\section{Chemistry}

Organophosphorus compounds such as phosphonate esters are generally prepared by the reaction of phosphonochloridates or phosphonodichloridates with alcohols. The use of phosphonochloridates is more common, and these compounds are prepared by the chlorination reaction of phosphonate diesters with phosphorus pentachloride $\left(\mathrm{PCl}_{5}\right)$, or by treatment of phosphonate monoesters with thionyl chloride $\left(\mathrm{SOCl}_{2}\right)$ or phosphonic acid $\left(\mathrm{H}_{3} \mathrm{PO}_{3}\right)$ with oxalyl chloride $(\mathrm{COCl})_{2}{ }^{20,21}$ Phosphorus oxychloride $\left(\mathrm{POCl}_{3}\right)$ leads to the formation of some side products, and therefore, it has not been employed in the synthesis of organophosphorus compounds. ${ }^{22}$ In this study, we employed $\mathrm{POCl}_{3}$ sucessfully in the synthesis of the desired products.

The 3-[(alkoxy-phosphoryloxy)-4,4,4-trifluorobutyl]-carbamic acid ethyl esters 2a-i were obtained through the reaction of (4,4,4-trifluoro-3-hydroxy-but1-yl)-carbamic acid ethyl esters 1a-c with phosphorus oxychloride, in toluene, in the presence of pyridine or triethylamine, under argon atmosphere, for $5 \mathrm{~h}$, at room temperature. The ethyl 3-(chlorophosphonyloxy)4,4,4-trifluorobutylcarbamate intermediates were not isolated, and the addition of an excess of alcohols to these intermediates, furnished the compounds $\mathbf{2} \mathbf{a}-\mathbf{i}$ as shown in Scheme 1. The synthesis of compounds $\mathbf{1 a - c}$ was described in a previous paper. ${ }^{23}$

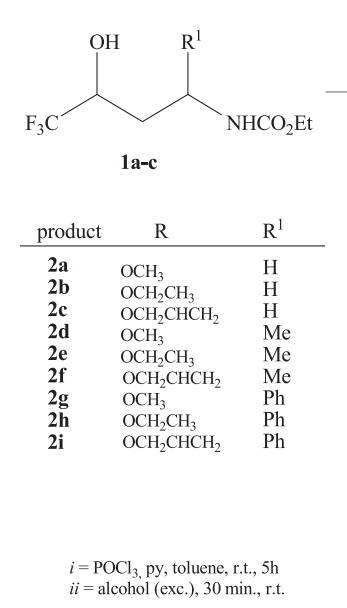

Scheme 1.

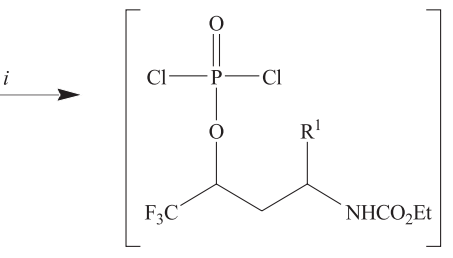

ii $30-98 \%$

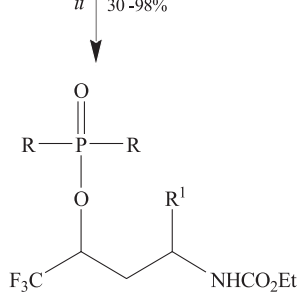

2a-i
When only an equivalent of the alcohols such as methanol, ethanol, iso-propyl, terc-butyl and benzyl were used, the reaction did not take place, and only the starting material was isolated. Other solvents, such as $\mathrm{CH}_{2} \mathrm{Cl}_{2}$ and $\mathrm{CHCl}_{3}$ were tested and did not furnish the desired products as well. When the reaction was carried out in THF the products were obtained but, in low yields. The products 2a-i were purified by silica gel column chromatography and were analyzed by ${ }^{1} \mathrm{H},{ }^{13} \mathrm{C},{ }^{19} \mathrm{~F}$ and ${ }^{31} \mathrm{P}$ NMR, GC-MS, and elemental analysis. These data are presented in the experimental section.

The formation of products $\mathbf{2 a - i}$ was evidenced by the following observations: $i$ ) typical multiplicity and coupling constants of the hydrogens located within 2 or 3 bonds from 
the phosphorous atom (e.g. the alkoxy groups attached to the phosphorous atom); ii) the broad-band decoupled ${ }^{13} \mathrm{C}$ NMR spectra showed doublets for the carbons within 2 or 3 bonds from the phosphorous atom; iii) the ${ }^{19} \mathrm{~F}$ and ${ }^{31} \mathrm{P}$ NMR spectra and the GC-MS spectra further confirm the structure of the obtained products.

There was a concern about the correct structure of products 2 because the intermediate phosphonodichloridates could undergo intramolecular cyclization furnishing cyclic products such as oxazafosforinanes. ${ }^{24}$ However, no evidence of the formation of cyclic oxazafosforinanes was found through the analysis of the ${ }^{1} \mathrm{H},{ }^{13} \mathrm{C},{ }^{19} \mathrm{~F}$, and ${ }^{31} \mathrm{P}$ NMR, as well as GC-MS spectra or through elemental analysis. Figure 1 shows the atom numbering used for the NMR assignment of compounds 2 .

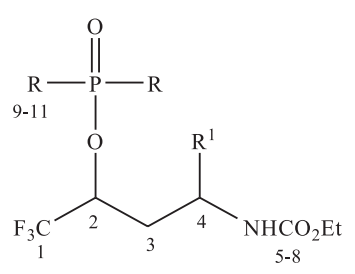

Figure 1. Atom numbering used for the NMR assignment of compounds 2.

\section{Biochemical screening and molecular modeling studies}

The synthesized compounds 2a-i were screened for AChE inhibitory activity at $1 \mu \mathrm{M}$, showing substantial inhibitory action (between 30 and 70\%). These results confirm that the designed synthetic compounds containing the combined pharmacophores phosphate-carbamate are new modulators of AChE. Within this series, compound $\mathbf{2 b}$ showed the most promising inhibitory effects (inhibition of $70 \%$ at $1 \mu \mathrm{M}$ ), while compounds $\mathbf{2 a}$ and $\mathbf{2 c}$, having a hydrogen in the $\mathrm{R}^{1}$ position (Scheme 1), showed inhibitions of 62 and 65\%, respectively. For compounds $2 \mathbf{d}, \mathbf{2 e}$ and $\mathbf{2 f}$, bearing a methyl group at the $\mathrm{R}^{1}$ position, the effects were less pronounced as percentage of inhibition decreased to 49 , 52 and $50 \%$, respectively. A more significant decrease in the inhibitory effects was observed for compounds $\mathbf{2 g}$ (34\%), $\mathbf{2 h}(38 \%)$ and $\mathbf{2 i}(30 \%)$, which have a phenyl group as the $\mathrm{R}^{1}$ substituent in their molecular structures. These results indicate that the presence of bulkier groups at the $\mathrm{R}^{1}$ has a negative impact on the modulation of AChE within this series of inhibitors combined pharmacophore characteristics. These interesting findings encourage us to extend our work with the aim of elucidating the possible binding mode of these compounds in the AChE active site. The understanding of the chemical basis involved in the complex process of molecular recognition and biological activity is of great importance in drug design. ${ }^{25}$ In this context, molecular modeling studies were carried out to investigate the preferred binding mode of this new series of synthetic AChE modulators possessing the two active pharmacophore moieties, which exhibit high capacity for intermolecular binding interactions in the protein active site.

The series of compounds 2a-i was analyzed in order to describe the possible interactions between the inhibitors and the amino acid residues of the active site, and from a region surrounding the cavity of the enzyme, called the peripheral site. Docking protocols as implemented in Flex $\mathrm{X}^{26,27}$ were employed to search the possible binding conformations of the ligands (2a-i, considering both $S$ and $R$ configurations) into the AChE binding site. The X-ray crystallographic data for $o$-ethylmethylphosphonylated AChE from Torpedo californica were retrieved from the Protein Data Bank (PDB code 1VXR). Considering the high homology between T. californica $\mathrm{AChE}$ and Electrophorus electricus $\mathrm{AChE}$, the crystallographic and biological data employed in this work are appropriate for the structural studies. Additionally, docking procedures as implemented in GOLD 3.0 were performed and the bioactive conformations obtained were in good agreement with those obtained with FlexX. AChE inhibitors $\mathbf{2 a}$ and $\mathbf{2 b}$ were the two of more significant results in the molecular modeling studies. For instance, Figure 2a shows the complex of AChE with the inhibitor $(\boldsymbol{S})$-2b, while Figure $2 \mathrm{~b}$ shows the AChE in complex with $(\boldsymbol{R})$-2b. Figure 2 depict intermolecular interactions in the active site found to be essential in stabilizing the transition state (for instance, the catalytic triad of residues Ser200, His440 and Glu327) as well as other important amino acid residues of the peripheral site.

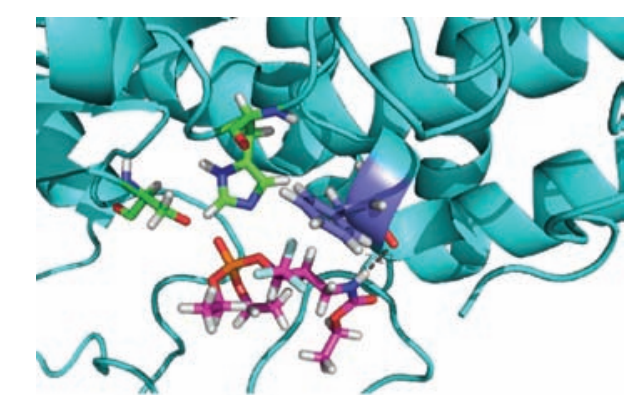

Figure 2a. Molecular interactions between $\mathrm{AChE}$ and the inhibitor (S)-2b, (displayed in pink). Residues of active site (Ser200 and His440) are displayed in green and residue of the peripheral site (Phe330) is displayed in violet. Hydrogen bond is shown in dashed lines.

As can be seen in Figure 2, the docking results (for all compounds) indicate that the phosphate group interacts with residue Ser200 of catalytic triad, playing an important role on the molecular recognition process as well as on the inhibitory effects of this series of phosphate-carbamate compounds. Additionally, inhibitors (S)-2a and (S)-2b 
seem to stabilize the active site through hydrogen bond interactions between their carbamate group and the residue Phe330 in the peripheral site. Distances of $1.85 \AA$ and $2.12 \AA$ were observed from the NH hydrogen of the carbamate group to the carbonyl oxygen of Phe 330 for 2a and $\mathbf{2 b}$, respectively (Figure 2a). Similar hydrogen bonds between the carbamate group and the carbonyl oxygen of Trp84 and hydroxyl hydrogen of Ser122 were found in inhibitors (R)-2a and (R)-2b (Figure 3).

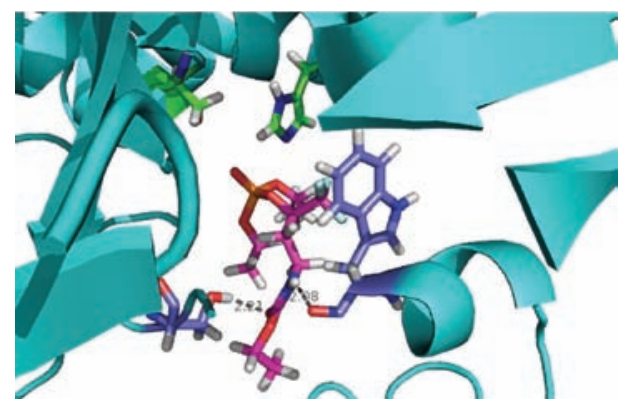

Figure 2b. Molecular interactions between $\mathrm{AChE}$ and the inhibitor (R)-2b, (displayed in pink). Residues of the active site (Ser200 and His440) are displayed in green and residues Trp 84 and Ser122 are displayed in violet. Hydrogen bond is shown in dashed lines.

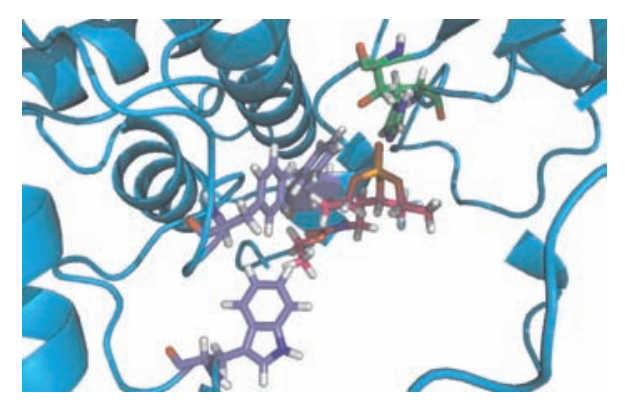

Figure 3. Hydrophobic contacts between the inhibitor $(\boldsymbol{S})$-2b (displayed in pink) and residues of the peripheral site (Trp279, Phe290 and Phe331, colored in violet).

Nearly $70 \%$ of the surface of the AChE cavity is covered by aromatic rings. Hydrophobic contacts between inhibitor (S)-2b and the aromatic side chains of the residues located in the peripheral site (Trp279, Phe290 and Phe331) are also important components in the stabilization of enzymeinhibitor complexes.

\section{Conclusion}

In this work, we have developed an efficient procedure for the preparation of phosphate-carbamate compounds from the reaction of (4,4,4-trifluoro-3-hydroxy-but-1-yl)carbamic acid ethyl esters with $\mathrm{POCl}_{3}$ followed by the addition of an appropriate alcohol. This synthetic approach employs inexpensive reagents, and the phosphonodichloridate intermediates underwent in situ conversion into the corresponding products by the addition of an excess of the alcohols, without the formation of cyclic oxazafosforinanes. The biochemical screening was important to reveal the AChE inhibitory effects for the new series of synthesized compounds. The molecular modeling studies allowed the identification of the possible binding mode of these compounds in the AChE active site. Together, the results provide valuable information on how this new molecular scaffold, represented by the compounds containing both active phosphate and carbamate pharmacophores, interacts with AChE. Nevertheless, it would be interesting to overcome some of the remaining challenges for the elucidation of the mechanism of action of this new class of AChE inhibitors with further biochemical evaluation and mechanism of action studies.

\section{Experimental}

Toluene was purified and dried before use and the $\gamma$-aminoalcohols (4,4,4-trifluoro-3-hydroxy-but-1-yl)carbamic acid ethyl esters were prepared according to the reference. ${ }^{23}$ Column chromatography was carried out in silica gel Aldrich 60A (230-400 mesh), using a mixture of adequate solvents. ${ }^{1} \mathrm{H}$ NMR spectra were registered on a Bruker DPX 200 spectrometer ( ${ }^{1} \mathrm{H}$ at $200.13 \mathrm{MHz}$ ) in $\mathrm{CDCl}_{3}$, using TMS as the internal reference. ${ }^{13} \mathrm{C},{ }^{31} \mathrm{P}$ and ${ }^{19} \mathrm{~F}$ NMR spectra were registered on a Bruker DPX 400 at 100.62, 162.00, and 376.5 $\mathrm{MHz}$, respectively, in $\mathrm{CDCl}_{3}$. TMS was used as the internal reference for the ${ }^{13} \mathrm{C}$ NMR spectra. Hydrogen broad-band decoupled ${ }^{31} \mathrm{P}$ NMR spectra were registered in $10 \mathrm{~mm}$ tubes, in $\mathrm{CDCl}_{3}$, using $\mathrm{H}_{3} \mathrm{PO}_{4}$ as the external reference (insert tube). ${ }^{19} \mathrm{~F}$ NMR spectra were registered in $5 \mathrm{~mm}$ tubes, in $\mathrm{CDCl}_{3}$ using fluorobenzene as the external reference (insert tube). Mass spectra were registered on a HP 5973 MSD connected to a HP 6890 GC and interfaced by a Pentium PC. The GC was equipped with a split-splitless injector, autosampler, crosslinked HP 5 capillary column ( $30 \mathrm{~m}$ of length, $0.32 \mathrm{~mm}$ of internal diameter, and $0.25 \mu \mathrm{m}$ of film thickness), and helium was used as the carrier gas. The $\mathrm{CHN}$ elemental analysis was performed on an EA 1110 Carlo Erba Instrument (University of São Paulo, São Carlos, SP, Brazil).

Acetylthiocholine iodide, acetylcholine acetylhydrolase (AChE from Electrophorus electricus) and DTNB (5,5'-dithiobis-2-nitrobenzoic acid) were purchased from Sigma Chemical Co. (St. Louis, MO, USA).

Molecular modeling studies were performed using the SYBYL 7.3 package (Tripos Inc., St. Louis, USA) run on Red Hat Enterprise Linux workstations, as previously described. ${ }^{26,27}$ The 3D structures of the inhibitors were constructed using standard geometric parameters of molecular modeling software package SYBYL 7.3. Each single optimized conformation of each molecule in the data 
set was energetically minimized employing Tripos force field and Gasteiger-Hückel charges.

\section{General procedure for the synthesis and purification of} compounds $2 a-i$

A solution of $\mathbf{1}(1.0 \mathrm{mmol})$ in toluene $(8.0 \mathrm{~mL})$ was stirred and refluxed under argon atmosphere in a Dean-Stark for $1 \mathrm{~h}$. The solution was allowed to cool at room temperature and pyridine $(0.16 \mathrm{~mL}, 2 \mathrm{mmol})$ was added. The solution was stirred for $5 \mathrm{~min}$ and then cooled at $0{ }^{\circ} \mathrm{C}$. $\mathrm{POCl}_{3}(0.1$ $\mathrm{mL}, 1 \mathrm{mmol}$ ) was added to the reaction and after $10 \mathrm{~min}$ the ice bath was removed. The stirring was continued for $5 \mathrm{~h}$ at room temperature when the presence of a solid was observed. Alcohols $(1 \mathrm{~mL})$ were added to the reaction vessel and stirring was continued for $0.5 \mathrm{~h}$ at room temperature. The solvent was removed by rotatory evaporator, $\mathrm{CH}_{2} \mathrm{Cl}_{2}(15 \mathrm{~mL})$ was added and the solution was washed with water $(3 \times 10 \mathrm{~mL})$. The aqueous layer was extracted with $\mathrm{CH}_{2} \mathrm{Cl}_{2}(2 \times 10 \mathrm{~mL})$. The organic layers were combined, dried $\left(\mathrm{MgSO}_{4}\right)$, and the solvent was removed by rotatory evaporator. Yields, ${ }^{1} \mathrm{H},{ }^{13} \mathrm{C},{ }^{31} \mathrm{P}$ and ${ }^{19} \mathrm{~F}$ NMR, and GC-MS data and the elemental analysis of the compounds are presented in the experimental section. The compounds 2a-i were purified by column chromatography on silica gel Aldrich 60A (230-400 Mesh), using chloroform with 1,2 or $5 \%$ of methanol as eluant; $1 \%$ (for $\mathbf{2 l}$ and $\mathbf{2 0}$ ), $2 \%$ (for 2a-b, 2d-e, 2g-h, 2k, and 2m) and 5\% (for 2c, 2f, 2i-j, 2n).

[3-(Dimethoxy-phosphate)-4,4,4-trifluoro-butyl]-carbamic acid ethyl ester (2a)

Yellow oil, 70\%; MS EI (70ev): $m / z(\%)=278\left(\mathrm{M}^{+}-45\right.$, 7), 127 (100), 109 (18); ${ }^{1} \mathrm{H}$ NMR ( $\mathrm{CDCl}_{3} / \mathrm{TMS}, 200.13$ $\mathrm{MHz}) \delta 1.23\left(\mathrm{t}, 3 \mathrm{H}, J_{\mathrm{H} 8-\mathrm{H} 7}=7.0 \mathrm{~Hz}, \mathrm{H}-8\right), 1.84-1.91(\mathrm{~m}$, $1 \mathrm{H}, \mathrm{H}-3), 2.08-2.10(\mathrm{~m}, 1 \mathrm{H}, \mathrm{H}-3), 3.17-3.20(\mathrm{~m}, 1 \mathrm{H}, \mathrm{H}-4)$, $3.55-3.63$ (m, 1H, H-4), 3.81 (d, 3Н, $\left.J_{\text {нө-Р }}=11.6 \mathrm{~Hz}, \mathrm{H}-9\right)$, $3.83\left(\mathrm{~d}, 3 \mathrm{H}, J_{\text {ня-Р }}=11.2 \mathrm{~Hz}, \mathrm{H}-9\right.$ '), $4.11\left(\mathrm{q}, 2 \mathrm{H}, J_{\mathrm{H} 7-\mathrm{H} 8}=7.0\right.$ $\mathrm{Hz}, \mathrm{H}-7$ ), $4.71-4.76$ (m, 1H, H-2), 5.66 (brs, $1 \mathrm{H}, \mathrm{NH}) ;{ }^{13} \mathrm{C}$ $\mathrm{NMR}\left(\mathrm{CDCl}_{3} / \mathrm{TMS}, 100 \mathrm{MHz}\right) \delta 14.2$ (C-8), 29.3 (C-3), 35.4 (C-4), $54.6(\mathrm{C}-9), 60.5(\mathrm{C}-7), 72.4\left(\mathrm{qd}, J_{\mathrm{C}-\mathrm{F}}=32.7 \mathrm{~Hz}, J_{\mathrm{C}-\mathrm{P}}=\right.$ $3.6 \mathrm{~Hz}, \mathrm{C}-2), 123.3\left(\mathrm{qd}, J_{\mathrm{C}-\mathrm{F}}=278.7 \mathrm{~Hz}, J_{\mathrm{C}-\mathrm{P}}=6.4 \mathrm{~Hz}, \mathrm{CF}_{3}\right.$ ), 156.6 (C-6); ${ }^{19} \mathrm{~F} \mathrm{NMR}\left(\mathrm{CDCl}_{3} /\right.$ fluorobenzene, $\left.376.5 \mathrm{MHz}\right) \delta$ -77.78; ${ }^{31} \mathrm{P} \mathrm{NMR}\left(\mathrm{CDCl}_{3} / \mathrm{H}_{3} \mathrm{PO}_{4}, 162.0 \mathrm{MHz}\right) \delta 0.92$; Anal. Calcd for $\mathrm{C}_{9} \mathrm{H}_{17} \mathrm{~F}_{3} \mathrm{NO}_{6} \mathrm{P}(323.21)$ : C, 33.45; H, 3.30; N, 4.33. Found: C, 33.45; H, 3.50; N, 4.33.

\section{[3-(Diethoxy-phosphate)-4,4,4-trifluoro-butyl]-carbamic} acid ethyl ester $(\mathbf{2 b})$

Yellow oil, 50\%; MS EI (70ev): $\mathrm{m} / z(\%)=306\left(\mathrm{M}^{+}-\right.$ 45, 10), 278 (5), 250 (17), 155 (100), 127 (57); ${ }^{1} \mathrm{H}$ NMR
$\left(\mathrm{CDCl}_{3} / \mathrm{TMS}, 200.13 \mathrm{MHz}\right) \delta 1.23\left(\mathrm{t}, 3 \mathrm{H}, J_{\mathrm{H} 8 \mathrm{-H} 7}=7.2 \mathrm{~Hz}\right.$, $\mathrm{H}-8$ ), 1.37 (dt, 3H, $J_{\mathrm{H} 10-\mathrm{H} 9}=7.0 \mathrm{~Hz}, J_{\mathrm{H} 10-\mathrm{P}}=1.2 \mathrm{~Hz}, \mathrm{H}-10$ ), $1.39\left(\mathrm{dt}, 3 \mathrm{H}, J_{\mathrm{H} 10^{\prime}-\mathrm{H} 9^{\prime}}=7.0 \mathrm{~Hz}, J_{\mathrm{H} 10^{\prime}-\mathrm{P}}=1.2 \mathrm{~Hz}, \mathrm{H}-10^{\prime}\right), 1.84$ - 1.93 (m, 1H, H-3), $2.05-2.18$ (m, 1H, H-3), $3.15-3.22$ (m, 1H, H-4), $3.60-3.66$ (m, 1H, H-4), $4.09-4.25$ (m, 6H, H-7, H-9, H-9'), 4.63 - 4.82 (m, 1H, H-2), 5.80 (brs, $1 \mathrm{H}, \mathrm{NH}) ;{ }^{13} \mathrm{C} \mathrm{NMR}\left(\mathrm{CDCl}_{3} / \mathrm{TMS}, 100 \mathrm{MHz}\right) \delta 15.6(\mathrm{C}-$ 8), $15.9\left(J_{\mathrm{C}-\mathrm{P}}=7.1 \mathrm{~Hz}, \mathrm{C}-10\right), 29.2(\mathrm{C}-3), 35.4(\mathrm{C}-4), 60.7$ $(\mathrm{C}-7), 63.5\left(\mathrm{~d}, J_{\mathrm{C}-\mathrm{P}}=5.6 \mathrm{~Hz}, \mathrm{C}-9\right), 64.7\left(\mathrm{~d}, J_{\mathrm{C}-\mathrm{P}}=6.6 \mathrm{~Hz}\right.$, C-9'), 72.2 (qd, $J_{\text {C-F }}=32.4 \mathrm{~Hz}, J_{\text {C-P }}=4.9 \mathrm{~Hz}, \mathrm{C}-2$ ), 123.5 $\left(\mathrm{qd}, J_{\mathrm{C}-\mathrm{F}}=278.8 \mathrm{~Hz}, J_{\mathrm{C}-\mathrm{P}}=6.3 \mathrm{~Hz}, \mathrm{CF}_{3}\right), 156.6(\mathrm{C}-6) ;{ }^{19} \mathrm{~F}$ NMR ( $\mathrm{CDCl}_{3} /$ fluorobenzene, $\left.376.5 \mathrm{MHz}\right) \delta-77.68 ;{ }^{31} \mathrm{P}$ $\mathrm{NMR}\left(\mathrm{CDCl}_{3} / \mathrm{H}_{3} \mathrm{PO}_{4}, 162.0 \mathrm{MHz}\right) \delta$-1.16; Anal. Calcd for $\mathrm{C}_{11} \mathrm{H}_{21} \mathrm{~F}_{3} \mathrm{NO}_{6} \mathrm{P}(351.26): \mathrm{C}, 37.61 ; \mathrm{H}, 6.03 ; \mathrm{N}, 3.99$. Found: C, 37.81; H, 6.01; N, 3.74.

[3-(Bis-allyloxy-phosphate)-4,4,4-trifluoro-butyl]-carbamic acid ethyl ester (2c)

Yellow oil, 40\%; MS EI (70ev): $m / z(\%)=330\left(\mathrm{M}^{+}-45\right.$, 6), 318 (6), 179 (100), 124 (22), 110 (10); ' $\mathrm{H}$ NMR ( $\mathrm{CDCl}_{3}$ ' TMS, $200.13 \mathrm{MHz}) \delta 1.20\left(\mathrm{t}, 3 \mathrm{H}, J_{\mathrm{H8}-\mathrm{H} 7}=6.6 \mathrm{~Hz}, \mathrm{H}-8\right)$, $1.74-1.88$ (m, 1H, H-3), $1.97-2.10(\mathrm{~m}, 1 \mathrm{H}, \mathrm{H}-3), 3.16$ -3.29 (m, 1H, H-4), $3.46-3.57$ (m, 1H, H-4), $4.06-4.16$ (m, 2H, H-7), $4.47-4.63$ (m, 4H, H-9), $4.66-4.76$ (m, $1 \mathrm{H}, \mathrm{H}-2), 5.16-5.43$ (m, 4H, H-11), $5.84-6.02$ (m, 2H, $\mathrm{H}-10) ;{ }^{13} \mathrm{C}$ NMR ( $\left.\mathrm{CDCl}_{3} / \mathrm{TMS}, 100 \mathrm{MHz}\right) \delta 14.4(\mathrm{C}-8)$, 29.0 (C-3), 35.3 (C-4), 60.6 (C-7), 68.0 (d, $J_{\mathrm{C}-\mathrm{P}}=5.8 \mathrm{~Hz}$, C-9), $68.8\left(\mathrm{~d}, J_{\mathrm{C}-\mathrm{P}}=5.4 \mathrm{~Hz}, \mathrm{C}-9\right.$ '), $72.3\left(\mathrm{qd}, J_{\mathrm{C}-\mathrm{F}}=32.7 \mathrm{~Hz}\right.$, $\left.J_{\mathrm{C}-\mathrm{P}}=4.3 \mathrm{~Hz}, \mathrm{C}-2\right), 118.1$ (C-11), 118.9 (C-11') 131.6 (d, $\left.J_{\mathrm{C}-\mathrm{P}}=7.1 \mathrm{~Hz}, \mathrm{C}-10\right), 132.2\left(\mathrm{~d}, J_{\mathrm{C}-\mathrm{P}}=7.0 \mathrm{~Hz}, \mathrm{C}-10\right.$ '), 156.6 (C-6); Anal. Calcd for $\mathrm{C}_{13} \mathrm{H}_{21} \mathrm{~F}_{3} \mathrm{~N}_{3} \mathrm{O}_{6} \mathrm{P}$ (375.28): C, 41.61; H, 5.64; N, 3.73. Found: C, 41.73; H, 5.95; N, 3.33.

[3-(Dimethoxy-phosphate)-4,4,4-trifluoro-1-methyl-butyl]carbamic acid ethyl ester $(\mathbf{2 d})$

Yellow oil, 98\%; MS EI (70ev): $m / z(\%)=292\left(\mathbf{M}^{+}-45\right.$, 7), 249 (2), 211 (5), 127 (100), 109 (21), 96 (15), 70 (26); ${ }^{1} \mathrm{H}$ NMR $\left(\mathrm{CDCl}_{3} / \mathrm{TMS}, 200.13 \mathrm{MHz}\right) \delta 1.23\left(\mathrm{t}, 3 \mathrm{H}, J_{\mathrm{H} 8 \mathrm{H} 7}\right.$ $=7.4 \mathrm{~Hz}, \mathrm{H}-8), 1.26\left(\mathrm{~d}, 3 \mathrm{H}, J_{\text {Сн3- } 44}=6.2 \mathrm{~Hz}, \mathrm{CH}_{3}\right), 1.83-$ $1.92(\mathrm{~m}, 1 \mathrm{H}, \mathrm{H}-3), 2.04-2.11(\mathrm{~m}, 1 \mathrm{H}, \mathrm{H}-3), 3.77$ (d, 3H, $\left.J_{\text {н9-Р }}=11.0 \mathrm{~Hz}, \mathrm{H}-9\right), 3.79$ (d, 3Н, $\left.\left.J_{\text {н9'-Р }}=10.8 \mathrm{~Hz}, \mathrm{H}^{-9}\right)^{\prime}\right)$, $3.85-3.97(\mathrm{~m}, 1 \mathrm{H}, \mathrm{H}-4), 4.10\left(\mathrm{q}, 2 \mathrm{H}, J_{\mathrm{H} 7 \mathrm{H} 8}=7.0 \mathrm{~Hz}, \mathrm{H}-7\right)$, $4.71-4.79$ (m, 1H, H-2), 5.00 (brs, $1 \mathrm{H}, \mathrm{NH}) ;{ }^{13} \mathrm{C}$ NMR $\left(\mathrm{CDCl}_{3} / \mathrm{TMS}, 100 \mathrm{MHz}\right) \delta 14.3(\mathrm{C}-8), 19.9\left(\mathrm{CH}_{3}\right), 36.2$ (C-3), 43.1 (C-4), 54.1 (d, $\left.J_{\mathrm{C}-\mathrm{P}}=5.5 \mathrm{~Hz}, \mathrm{C}-9\right), 54.5$ (d, $J_{\mathrm{C}-\mathrm{P}}$ $=6.3 \mathrm{~Hz}, \mathrm{C}-9), 60.5(\mathrm{C}-7), 72.5\left(\mathrm{qd}, J_{\mathrm{C}-\mathrm{F}}=33.0 \mathrm{~Hz}, J_{\mathrm{C}-\mathrm{P}}\right.$ $=5.0 \mathrm{~Hz}, \mathrm{C}-2), 123.3\left(\mathrm{qd}, J_{\mathrm{C}-\mathrm{F}}=279.3 \mathrm{~Hz}, J_{\mathrm{C}-\mathrm{P}}=5.9 \mathrm{~Hz}\right.$, $\mathrm{CF}_{3}$ ), $155.8(\mathrm{C}-6) ;{ }^{19} \mathrm{~F}$ NMR ( $\mathrm{CDCl}_{3} /$ fluorobenzene, 376.5 $\mathrm{MHz}) \delta$-77.94; ${ }^{31} \mathrm{P} \mathrm{NMR}\left(\mathrm{CDCl}_{3} / \mathrm{H}_{3} \mathrm{PO}_{4}, 162.0 \mathrm{MHz}\right) \delta$ 
-0.22; Anal. Calcd for $\mathrm{C}_{10} \mathrm{H}_{19} \mathrm{~F}_{3} \mathrm{NO}_{6} \mathrm{P}$ (337.23): C, 35.62; H, 5.68; N, 4.15. Found: C, 35.63; H, 5.71; N, 4.06.

\section{[3-(Diethoxy-phosphate)-4,4,4-trifluoro-1-methyl-butyl]-} carbamic acid ethyl ester (2e)

Yellow oil, 43\%; MS EI (70ev): $m / z(\%)=320\left(\mathrm{M}^{+}-45\right.$, 10), 292 (3), 250 (14), 155 (100), 127 (42), 70 (25); ${ }^{1} \mathrm{H}$ $\mathrm{NMR}\left(\mathrm{CDCl}_{3} / \mathrm{TMS}, 200.13 \mathrm{MHz}\right) \delta 1.23\left(\mathrm{t}, 3 \mathrm{H}, J_{\mathrm{H} 8-\mathrm{H} 7}=\right.$ $6.8 \mathrm{~Hz}, \mathrm{H}-8), 1.26\left(\mathrm{~d}, 3 \mathrm{H}, J_{\text {Сн3- } 44}=6.4 \mathrm{~Hz}, \mathrm{CH}_{3}\right), 1.34(\mathrm{dt}$, $\left.3 \mathrm{H}, J_{\mathrm{H} 10-\mathrm{H} 9}=7.2 \mathrm{~Hz}, J_{\mathrm{H} 10-\mathrm{P}}=0.8 \mathrm{~Hz}, \mathrm{H}-10\right), 1.37(\mathrm{dt}, 3 \mathrm{H}$, $\left.J_{{\mathrm{H} 10^{\prime}-\mathrm{H} 9^{\prime}}^{\prime}}=7.2 \mathrm{~Hz}, J_{{\mathrm{H} 10^{\prime}-\mathrm{P}}}=0.8 \mathrm{~Hz}, \mathrm{H}-10^{\prime}\right), 1.86-1.90(\mathrm{~m}$, $1 \mathrm{H}, \mathrm{H}-3), 2.05-2.12$ (m, 1H, H-3), $3.90-3.93(\mathrm{~m}, 1 \mathrm{H}$, $\mathrm{H}-4), 4.10\left(\mathrm{q}, 2 \mathrm{H}, J_{\mathrm{H} 7-\mathrm{H} 8}=6.8 \mathrm{~Hz}, \mathrm{H}-7\right), 4.07-4.22(\mathrm{~m}$, 6H, H-7, H-9, H-9'), 4.70 - 4.75 (m, 1H, H-2), 5.01 (brs, $1 \mathrm{H}, \mathrm{NH}) ;{ }^{13} \mathrm{C} \mathrm{NMR}\left(\mathrm{CDCl}_{3} / \mathrm{TMS}, 100 \mathrm{MHz}\right) \delta 14.4(\mathrm{C}-8)$, $15.9\left(\mathrm{~d}, J_{\mathrm{C}-\mathrm{P}}=7.8 \mathrm{~Hz}, \mathrm{C}-10\right), 16.0\left(\mathrm{~d}, J_{\mathrm{C}-\mathrm{P}}=6.1 \mathrm{~Hz}, \mathrm{C}-10\right)$, $20.4\left(\mathrm{CH}_{3}\right), 36.3(\mathrm{C}-3), 43.4(\mathrm{C}-4), 60.6(\mathrm{C}-7), 63.5(\mathrm{~d}$, $\left.J_{\text {C-P }}=5.7 \mathrm{~Hz}, \mathrm{C}-9\right), 64.5\left(\mathrm{~d}, J_{\mathrm{C}-\mathrm{P}}=6.7 \mathrm{~Hz}, \mathrm{C}-9^{\prime}\right), 72.3(\mathrm{qd}$, $\left.J_{\text {C-F }}=33.0 \mathrm{~Hz}, J_{\mathrm{C}-\mathrm{P}}=4.8 \mathrm{~Hz}, \mathrm{C}-2\right), 123.5\left(\mathrm{qd}, J_{\mathrm{C}-\mathrm{F}}=278.8\right.$ $\left.\mathrm{Hz}, J_{\mathrm{C}-\mathrm{P}}=6.3 \mathrm{~Hz}, \mathrm{CF}_{3}\right), 155.8(\mathrm{C}-6) ;{ }^{19} \mathrm{~F} \mathrm{NMR}\left(\mathrm{CDCl}_{3} /\right.$ fluorobenzene, $376.5 \mathrm{MHz}) \delta-77.86$; ${ }^{31} \mathrm{P} \mathrm{NMR}\left(\mathrm{CDCl}_{3} /\right.$ $\left.\mathrm{H}_{3} \mathrm{PO}_{4}, 162.0 \mathrm{MHz}\right) \delta$-1.76; Anal. Calcd for $\mathrm{C}_{12} \mathrm{H}_{23} \mathrm{~F}_{3} \mathrm{NO}_{6} \mathrm{P}$ (365.28): C, 39.46; H, 6.35; N, 3.83. Found: C, 39.46; H, $6.35 ; \mathrm{N}, 3.83$.

[3-(Bis-allyloxy-phosphate)-4,4,4-trifluoro-1-methylbutyl]-carbamic acid ethyl ester (2f)

Yellow oil, 40\%; MS EI (70ev): $\mathrm{m} / z(\%)=344\left(\mathrm{M}^{+}-\right.$ 45, 6), 179 (100), 211 (15), 139 (36), 124 (39); ${ }^{1} \mathrm{H}$ NMR $\left(\mathrm{CDCl}_{3} / \mathrm{TMS}, 200.13 \mathrm{MHz}\right) \delta 1.23\left(\mathrm{t}, 6 \mathrm{H}, J_{\mathrm{H} 8 \mathrm{-H} 7}=7.0 \mathrm{~Hz}\right.$, $\left.\mathrm{H}-8, \mathrm{CH}_{3}\right), 1.83-1.94(\mathrm{~m}, 1 \mathrm{H}, \mathrm{H}-3), 2.02-2.17$ (m, 1H, $\mathrm{H}-3), 3.89-3.92(\mathrm{~m}, 1 \mathrm{H}, \mathrm{H}-4), 4.10\left(\mathrm{q}, 2 \mathrm{H}, J_{\mathrm{H}-\mathrm{H} 8}=7.0 \mathrm{~Hz}\right.$, H-7), 4.53 - 4.64 (m, 4H, H-9), 4.69 - 4.81 (m, 1H, H-2), $5.23-5.44$ (m, 4H, H-11), $5.86-6.03$ (m, $2 \mathrm{H}, \mathrm{H}-10) ;{ }^{13} \mathrm{C}$ NMR $\left(\mathrm{CDCl}_{3} / \mathrm{TMS}, 100 \mathrm{MHz}\right) \delta 14.2(\mathrm{C}-8), 19.9\left(\mathrm{CH}_{3}\right)$, 36.0 (C-3), 43.0 (C-4), 60.2 (C-7), 67.9 (d, $J_{\mathrm{C}-\mathrm{P}}=4.9 \mathrm{~Hz}$, C-9), $68.5\left(\mathrm{~d}, J_{\mathrm{C}-\mathrm{P}}=6.3 \mathrm{~Hz}, \mathrm{C}-9\right.$ '), $72.6\left(\mathrm{qd}, J_{\mathrm{C}-\mathrm{F}}=33.7 \mathrm{~Hz}\right.$, $\left.J_{\text {C-P }}=5.1 \mathrm{~Hz}, \mathrm{C}-2\right), 117.1\left(\mathrm{~d}, J_{\mathrm{C}-\mathrm{P}}=4.2 \mathrm{~Hz}, \mathrm{C}-11\right), 118.4(\mathrm{~d}$, $\left.J_{\text {C-P }}=6.9 \mathrm{~Hz}, \mathrm{C}-11\right), 123.2\left(\mathrm{qd}, J_{\mathrm{C}-\mathrm{F}}=278.2 \mathrm{~Hz}, J_{\mathrm{C}-\mathrm{P}}=6.0\right.$ $\left.\mathrm{Hz}, \mathrm{CF}_{3}\right), 131.6$ (d, $\left.J_{\text {C-P }}=4.0 \mathrm{~Hz}, \mathrm{C}-10\right), 132.0\left(\mathrm{~d}, J_{\mathrm{C}-\mathrm{P}}=\right.$ $6.9 \mathrm{~Hz}, \mathrm{C}-10), 155.8$ (C-6); Anal. Calcd for $\mathrm{C}_{14} \mathrm{H}_{23} \mathrm{~F}_{3} \mathrm{NO}_{6} \mathrm{P}$ (389.31): C, 43.19; H, 5.95; N, 3.60. Found: C, 42.63; H, $5.39 ; \mathrm{N}, 3.49$.

[3-(Dimethoxy-phosphate)-4,4,4-trifluoro-1-phenyl-butyl]carbamic acid ethyl ester (2g)

Yellow oil, 40\%; MS EI (70ev): $m / z(\%)=399(2)$, 273 (16), 244 (100), 200 (68), 77 (29); ${ }^{1} \mathrm{H}$ NMR $\left(\mathrm{CDCl}_{3} /\right.$
TMS, 200.13 MHz) $\delta 1.20\left(\mathrm{t}, 3 \mathrm{H}, J_{\mathrm{H} 8-\mathrm{H} 7}=7.0 \mathrm{~Hz}, \mathrm{H}-8\right)$, 2.28-2.48 (m, 2H, H-3), 3.77 (d, 3H, $J_{\text {н9-Р }}=11.2 \mathrm{~Hz}, \mathrm{H}-9$ ), $3.84\left(\mathrm{~d}, 3 \mathrm{H}, J_{\mathrm{H}^{\prime}-\mathrm{P}}=11.2 \mathrm{~Hz}, \mathrm{H}-9^{\prime}\right), 4.08\left(\mathrm{q}, 2 \mathrm{H}, J_{\mathrm{H} 7-\mathrm{H} 8}=\right.$ $7.0 \mathrm{~Hz}, \mathrm{H}-7), 4.46-4.60$ (m, 1H, H-2), 4.88 (m, 1H, H-4), $5.63\left(\mathrm{~d}, 1 \mathrm{H}, J_{\mathrm{NH}-\mathrm{H} 4}=7.2 \mathrm{~Hz}, \mathrm{NH}\right), 7.28-7.36(\mathrm{~m}, 5 \mathrm{H}, \mathrm{Ph})$; ${ }^{13} \mathrm{C} \mathrm{NMR}\left(\mathrm{CDCl}_{3} / \mathrm{TMS}, 100 \mathrm{MHz}\right) \delta 14.3(\mathrm{C}-8), 36.3(\mathrm{C}-$ 3), $51.6(\mathrm{C}-4), 54.6$ (d, $\left.J_{\mathrm{C}-\mathrm{P}}=6.4 \mathrm{~Hz}, \mathrm{C}-9\right), 54.8\left(\mathrm{~d}, J_{\mathrm{C}-\mathrm{P}}=\right.$ $5.6 \mathrm{~Hz}, \mathrm{C}-9$ '), $60.8(\mathrm{C}-7), 72.4\left(\mathrm{qd}, J_{\mathrm{C}-\mathrm{F}}=33.0 \mathrm{~Hz}, J_{\mathrm{C}-\mathrm{P}}=\right.$ $4.8 \mathrm{~Hz}, \mathrm{C}-2), 126.6,128.0,128.9,140.1$ (6C, Ph), 123.4 $\left(\mathrm{qd}, J_{\mathrm{C}-\mathrm{F}}=280.0 \mathrm{~Hz}, J_{\mathrm{C}-\mathrm{P}}=5.7 \mathrm{~Hz}, \mathrm{CF}_{3}\right), 155.7(\mathrm{C}-6) ;{ }^{19} \mathrm{~F}$ NMR ( $\mathrm{CDCl}_{3} /$ fluorobenzene, $\left.376.5 \mathrm{MHz}\right) \delta-77.98 ;{ }^{31} \mathrm{P}$ $\mathrm{NMR}\left(\mathrm{CDCl}_{3} / \mathrm{H}_{3} \mathrm{PO}_{4}, 162.0 \mathrm{MHz}\right) \delta-0.19$; Anal. Calcd for $\mathrm{C}_{19} \mathrm{H}_{25} \mathrm{~F}_{3} \mathrm{NO}_{6} \mathrm{P}$ (451.38): C, 45.12; H, 5.30; N, 3.51. Found: C, 45.14; H, 5.33; N, 3.39.

[3-(Diethoxy-phosphate)-4,4,4-trifluoro-1-phenyl-butyl]carbamic acid ethyl ester (2h)

Yellow oil, 33\%; MS EI (70ev): $m / z(\%)=427\left(\mathbf{M}^{+}, 4\right)$, 382 (2), 272 (16), 244 (100), 200 (66), 155 (97), 127 (36), 77 (22); ${ }^{1} \mathrm{H} \mathrm{NMR}\left(\mathrm{CDCl}_{3} / \mathrm{TMS}, 200.13 \mathrm{MHz}\right) \delta 1.20(\mathrm{t}, 3 \mathrm{H}$, $\left.J_{\mathrm{H} 8-\mathrm{H} 7}=7.0 \mathrm{~Hz}, \mathrm{H}-8\right), 1.33\left(\mathrm{t}, 3 \mathrm{H}, J_{\mathrm{H} 10 \mathrm{-H} 9}=7.0 \mathrm{~Hz}, \mathrm{H}-10\right)$, $1.37\left(\mathrm{t}, 3 \mathrm{H}, J_{\mathrm{H}^{\circ} 0^{-} \mathrm{H} 9^{\prime}}=7.0 \mathrm{~Hz}, \mathrm{H}-10^{\prime}\right), 2.28-2.39(\mathrm{~m}, 2 \mathrm{H}$, H-3), 4.03 - 4.23 (m, 6H, H-7, H-9, H-9'), 4.48 - 4.62 (m, $1 \mathrm{H}, \mathrm{H}-2), 4.90(\mathrm{~m}, 1 \mathrm{H}, \mathrm{H}-4), 5.71\left(\mathrm{~d}, 1 \mathrm{H}, J_{\mathrm{NH}-\mathrm{H} 4}=7.2 \mathrm{~Hz}\right.$, $\mathrm{NH}), 7.28-7.41(\mathrm{~m}, 5 \mathrm{H}, \mathrm{Ph}) ;{ }^{13} \mathrm{C} \mathrm{NMR}\left(\mathrm{CDCl}_{3} / \mathrm{TMS}, 100\right.$ $\mathrm{MHz}) \delta 14.4(\mathrm{C}-8), 15.8$ (d, $\left.J_{\mathrm{C}-\mathrm{P}}=7.2 \mathrm{~Hz}, \mathrm{C}-10\right), 15.9$ (d, $\left.J_{\mathrm{C}-\mathrm{P}}=6.4 \mathrm{~Hz}, \mathrm{C}-10^{\prime}\right), 36.5(\mathrm{C}-3), 51.7$ (C-4), 60.8 (C-7), $63.5\left(\mathrm{~d}, J_{\mathrm{C}-\mathrm{P}}=5.5 \mathrm{~Hz}, \mathrm{C}-9\right), 64.6\left(\mathrm{~d}, J_{\mathrm{C}-\mathrm{P}}=6.4 \mathrm{~Hz}, \mathrm{C}-9\right.$ '), $72.2\left(\mathrm{qd}, J_{\mathrm{C}-\mathrm{F}}=32.5 \mathrm{~Hz}, J_{\mathrm{C}-\mathrm{P}}=4.8 \mathrm{~Hz}, \mathrm{C}-2\right), 126.3(\mathrm{qd}$, $\left.J_{\mathrm{C}-\mathrm{F}}=230.9 \mathrm{~Hz}, \mathrm{CF}_{3}\right), 126.5,127.9,128.8,140.4(6 \mathrm{C}, \mathrm{Ph})$, 155.7 (C-6); ${ }^{19} \mathrm{~F} \mathrm{NMR}\left(\mathrm{CDCl}_{3} /\right.$ fluorobenzene, $\left.376.5 \mathrm{MHz}\right)$ $\delta$-77.89; ${ }^{31} \mathrm{P} \mathrm{NMR}\left(\mathrm{CDCl}_{3} / \mathrm{H}_{3} \mathrm{PO}_{4}, 162.0 \mathrm{MHz}\right) \delta-0.99$; Anal. Calcd for $\mathrm{C}_{17} \mathrm{H}_{25} \mathrm{~F}_{3} \mathrm{NO}_{6} \mathrm{P}(427.35)$ : C, 47.78; H, 5.90; N, 3.28. Found: C, 47.40; H, 5.22; N, 3.87.

[3-(Bis-allyloxy-phosphate)-4,4,4-trifluoro-1-phenylbutyl]-carbamic acid ethyl ester (2i)

Yellow oil, 30\%; MS EI (70ev): $m / z(\%)=451\left(\mathbf{M}^{+}, 3\right)$, 272 (29), 244 (100), 200 (76), 179 (63), 79 (32), 57 (12); ${ }^{1} \mathrm{H} \mathrm{NMR}\left(\mathrm{CDCl}_{3} / \mathrm{TMS}, 200.13 \mathrm{MHz}\right) \delta 1.12\left(\mathrm{t}, 3 \mathrm{H}, \mathrm{J}_{\mathrm{H} 8 \mathrm{-H} 7}=\right.$ $7.2 \mathrm{~Hz}, \mathrm{H}-8), 2.16-2.37(\mathrm{~m}, 2 \mathrm{H}, \mathrm{H}-3), 4.01\left(\mathrm{q}, 2 \mathrm{H}, J_{\mathrm{H} 7 \mathrm{H} 8}=\right.$ $7.2 \mathrm{~Hz}, \mathrm{H}-7), 4.09-4.16$ (m, 1H, H-4), 4.36 - 4.63 (m, $5 \mathrm{H}, \mathrm{H}-9, \mathrm{H}-2), 5.13-5.44$ (m, 4H, H-11), $5.81-6.00$ (m, $2 \mathrm{H}, \mathrm{H}-10), 7.19-7.63(5 \mathrm{H}, \mathrm{Ph}) ;{ }^{13} \mathrm{C}$ NMR $\left(\mathrm{CDCl}_{3} / \mathrm{TMS}\right.$, $100 \mathrm{MHz}) \delta 14.4$ (C-8), 36.4 (C-3), 44.5 (C-4), 60.9 (C-7), $68.1\left(\mathrm{~d}, J_{\mathrm{C}-\mathrm{P}}=3.4 \mathrm{~Hz}, \mathrm{C}-9\right), 68.8\left(\mathrm{~d}, J_{\mathrm{C}-\mathrm{P}}=5.6 \mathrm{~Hz}, \mathrm{C}-9\right.$ '), $72.4\left(\mathrm{qd}, J_{\mathrm{C}-\mathrm{F}}=33.10 \mathrm{~Hz}, J_{\mathrm{C}-\mathrm{P}}=4.8 \mathrm{~Hz}, \mathrm{C}-2\right), 118.2(\mathrm{C}-11)$, 118.7 (C-11'), 123.4 (qd, $J_{\text {C-F }}=280.0 \mathrm{~Hz}, J_{\mathrm{C}-\mathrm{P}}=6.2 \mathrm{~Hz}$, $\left.\mathrm{CF}_{3}\right), 126.5,128.0,128.9,140.3(\mathrm{Ph}), 131.8\left(\mathrm{~d}, J_{\mathrm{C}-\mathrm{P}}=7.0\right.$ 
$\mathrm{Hz}, \mathrm{C}-10), 132.2$ (d, $J_{\mathrm{C}-\mathrm{P}}=6.2 \mathrm{~Hz}, \mathrm{C}-10$ '), 155.8 (C-6); Anal. Calcd for $\mathrm{C}_{19} \mathrm{H}_{25} \mathrm{~F}_{3} \mathrm{NO}_{6} \mathrm{P}$ (451.38): C, 50.56; H, 5.58; N, 3.10. Found: C, 50.64; H, 5.43; N 3.38.

\section{Acetylcholinesterase assays}

All compounds 2a-i were tested at $1 \mu \mathrm{M}$ for $\mathrm{AChE}$ (from Electrophorus electricus, Sigma Chemical Co.) inhibitory activity employing the spectrophotometric method of Ellman, as previously described. ${ }^{24,28}$

\section{Molecular modeling studies}

Docking protocol as implemented in FlexX (SYBYL 7.3) and in GOLD 2.1 (Cambridge Crystallographic Data Centre, Cambridge, UK) was employed to search for the possible binding conformations of ligands in the AChE binding site. Crystallographic data for AChE in complex with $o$-ethylmethylphosphonic acid ester used in simulations in the FlexX were retrieved from Protein Data Bank (PDB code: 1VXR), to which removed the ligand from the active site, water molecules were removed and hydrogen atoms were added in standard geometry using the Biopolymer module as implemented in SYBYL 7.3.

\section{Acknowledgments}

The authors thank the financial support from Conselho Nacional de Desenvolvimento Científico e Tecnológico (CNPq - Universal grant No. 476634/06-7), and fellowships (D. M. Borchhardt and T.M. Marchi).

\section{References}

1. Moore, J. D.; Sprott, K. T.; Wrobleski, A. D.; Hanson, P. R.; Org. Lett. 2002, 4, 2357.

2. Palacios, F.; Alonso, C.; Santos, J. M.; Chem. Review 2005, $105,899$.

3. Lin, G.; Lai, C. Y.; Liao, W. C.; Bioorg. Med. Chem. 1999, 7, 2683.

4. Silman, I.; Sussman, J. L.; Curr. Opin. Pharmacol. 2005, 5, 293.

5. Hurley, M. M.; Balboa, A.; Lushington, G. H.; Guo, J.; Chem.Biol. Interact. 2005, 157, 321.

6. Costa, L. G.; Clin. Chim. Acta 2006, 366, 1.

7. Chambers, H. W.; Organophosphorus Compounds: An Overview. In Organophosphorus - Chemistry, Fate and Effects. Academic Press: San Diego, 1992, p. 3-17.

8. Villate, F.; Marcel, V.; Mondaca, S. E.; Fournier, D.; Biosens. Bioelectron. 1998, 13, 157.
9. Shaohong, L.; Kumagai, T.; Qinghua, A.; Xiaolan, Y.; Ohmae, H.; Yabu, Y.; Siwen, L.; Liyong, W.; Maruyama, H.; Ohta, N.; Parasitol. Intern. 2006, 55, 63.

10. Thompson, C. M.; Suarez, A. I.; Rodriguez, O. P.; Chem. Res. Toxicol. 1996, 9, 1325; Spaulding, R. S.; George, K. M.; Thompson, C. M.; J. Chromatography 2006, 830, 105.

11. Saxena, R.; Prakash, J.; Mathur, P.; Gupta, S. K.; J. Pharmacol. 2002, 34, 71 .

12. Midgai, C.; Ophtalmology 1994, 101, 1651.

13. Mustazza, C.; Borioni, A.; Giudice, M. R. D.; Gatta, F.; Ferreti, R.; Meneguz, A.; Volpe, M. T.; Lorenzini, P.; Eur. J. Med. Chem. 2002, 37, 91.

14. Carlton, F. B.; Simpson, W. M.; Haddad, L. M.; The Organophosphate and other Inseticides. Clinical Management of Poisoning and Drug Overdose, Philadelphia, Pensylvania, USA, WB Saunders Company, $3^{\text {rd }}$ ed., 1998, 836.

15. Sogorb, M. A.; Vilanova, E.; Toxicol. Lett. 2002, 128, 215.

16. Breyer-Pfaff, U.; Maier, U.; Brinkmann, A. M.; Schumm, F.; Clin. Pharmacol. Therapy 1985, 37, 495.

17. Kuhr, R. J.; Dorough, H. W.; Carbamate Insecticides: Chemistry, Biochemistry and Toxicology; CRC Press: Cleveland, 1976, pp. 41-70.

18. Safadi, M.; Oliyai, R.; Stella, V. J.; Pharm. Res. 1993, 10, 1350.

19. Chambers, J. R.; Isbell, A. F.; J. Org. Chem. 1962, 29, 832.

20. Hirschman, R.; Yager, K. M.; Taylor, C. M.; Moore, W.; Sprengeler, P. A.; Witherington, J.; Phillips, B. W.; Smith, A. B.; J. Am. Chem. Soc. 1995, 117, 6370.

21. Musiol, H. J.; Grams, F.; Böhner, S. R.; Moroder, L.; J. Org. Chem. 1994, 59, 6144.

22. Rogers, R. S.; Tetrahedron Lett. 1992, 33, 7473.

23. Zanatta, N.; Borchhardt, D. M.; Alves, S. H.; Coelho, H. S.; Squizani, A. M. C.; Marchi, T. M.; Bonacorso, H. G.; Martins, M. A. P.; Bioorg. Med. Chem. 2006, 14, 3174.

24. Maynard-Faure, P.; Gonser, C.; Vaime, V.; Bouchu, D.; Tetrahedron Lett. 1998, 39, 2315; Lilo, B.; Moreau, M.; Bouchu, D.; Tetrahedron Lett. 1990, 31, 887.

25. Castilho, M. S.; Postigo, M. P.; de Paula, C. C. B.; Montanari, V. A.; Oliva, G.; Andricopulo, A. D.; Bioorg. Med. Chem. 2006, $14,516$.

26. Honorio, K. M.; Garratt, R. C.; Andricopulo, A. D.; Bioorg. Med. Chem. Lett. 2005, 15, 3119.

27. Salum, L. B.; Polikarpov, I.; Andricopulo, A. D.; J. Mol. Graph. Modell. 2007, 26, 434.

28. Ellman, G. L.; Courtney, D. K.; Andres, V.; Featherstone, R. M.; Biochem. Pharmacol. 1961, 7, 88.

Received: November 20, 2007 Web Release Date: July 11, 2008

FAPESP helped in meeting the publication costs of this article. 